UMBARA

Indonesian Journal of Anthropology

Volume 6 (2) Desember 2021 || eISSN 2528-1569 | pISSN 2528-2115 || http://jurnal.unpad.ac.id/umbara

DOI : 10.24198/umbara.v6i2.33710

\title{
Bersandar Kapas, Berujung Bencana: \\ Perspektif Ekonomi Politik dalam Sejarah Perdagangan Kapas di Flores, 1912-1943
}

\author{
Martin Elvanyus De Porres \\ Pascasarjana Antropologi, Fakultas Ilmu Budaya, Universitas Gadjah Mada \\ elvanporres@gmail.com
}

\begin{abstract}
This study discusses the historical process of cotton introduction and commercialization in Maumere, Sikka Regency, Flores, East Nusa Tenggara, from 1912 to 1943 using political economy perspective. In the early 20th century, the Netherlands enacted the 1870 Agrarian Law. Flores was one of the areas officially colonized by the Dutch. A number of crop commodities were introduced, including the establishment of plantations, to participate in global trade traffic. Cotton is one of the plants introduced to Flores for the benefit of the world's textile industry. The people of Flores were forced to plant, but along the way, the plants did not succeed in providing surplus value to trading companies, let alone to local people. This study was conducted based on literature. This study finds that the power relations between the Dutch East Indies government, trading companies, and local rulers, led to the forced commercialization. This interwoven political economy relationship had an impact on the existence of a primitive and capital accumulation mechanism. The mechanism causes local residents to lose land and shelter and some of them fall into forced labor to serve the feudal elite and colonial rulers.
\end{abstract}

Keywords: cotton, Flores, colonialism, feudalism, commercialization

\begin{abstract}
Abstrak
Studi ini menjelaskan proses historis komersialisasi kapas di Maumere, Kabupaten Sikka, Flores, Nusa Tenggara Timur, dari tahun 1912 hingga 1943 menggunakan perspektif ekonomi politik. Pada awal abad ke-20, Belanda menetapkan Undang-Undang Agraria 1870 dan secara resmi menjajah Flores. Sejumlah tanaman komoditas diperkenalkan, termasuk pembukaan perkebunan, untuk diikutsertakan dalam lalu lintas perdagangan global. Kapas menjadi salah satu tanaman yang diintroduksi di Flores untuk dibudidaya demi kepentingan industri tekstil dunia. Masyarakat Flores pun dipaksa menanam, tetapi dalam perjalanannya tanaman itu tidak berhasil memberikan nilai lebih untuk perusahaan dagang, apalagi bagi rakyat tempatan. Penelitian ini dilakukan dengan metode studi literatur. Hasil studi menemukan hubungan kekuasaan antara pemerintah Hindia Belanda, perusahaan dagang, dan para penguasa lokal, yang kemudian berujung pada adanya pemaksaan komersialisasi. Jalinan relasi ekonomi politik tersebut berdampak pada munculnya mekanisme akumulasi primitif dan kapital. Kondisi tersebut menyebabkan penduduk lokal kehilangan lahan dan tempat tinggal, dan sebagiannya lagi terjerumus menjadi tenaga kerja paksa untuk melayani elite feodal dan penguasa kolonial.
\end{abstract}

Kata kunci: kapas, Flores, kolonialisme, feodalisme, komersialisasi 


\section{Pendahuluan}

Pembukaan Terusan Suez pada tahun 1869 menyebabkan semakin lancarnya hubungan Eropa dan Asia, terutama dalam bidang perekonomian. Sarana dan prasarana transportasi pun dibangun untuk menunjang kepentingan ekonomi tersebut, seperti adanya moda maskapai pelayaran swasta Stoomvaart Maatschappij Nederland (SMV) tahun 1870 dan Rotterdamsche Lloyd (RL) pada 1873 (Mulya, 2018) serta pembukaan jalur kereta api di Pulau Jawa dan Sumatera. Sarana dan prasarana tersebut digunakan untuk mengangkut barang-barang produksi dari wilayah jajahan Hindia Belanda ke Amsterdam dan Eropa Barat.

Barang-barang produksi tersebut merupakan hasil perkebunan dan pertambangan sebagai implikasi dari penetapan produk hukum Agrarische Wet tahun 1870 tentang administrasi tanah. Di dalam konteks parlemen Hindia Belanda, produk hukum ini merupakan desakan kaum liberal untuk mengembangkan usaha dagang alias liberalisasi tanah jajahan sekaligus respons dari peninjauan kembali program Cultuurstelsel sejak tahun 1830-an (Sondarika, 2015; Zulkarnain, 2010). Tanah jajahan pun dibuka, modal partikelir diinvestasikan, termasuk pendirian pabrik-pabrik dan pengenalan teknologi produksi modern. Perkebunan teh, tebu, kopi, dan tembakau banyak bermunculan, terutama di Jawa, Sumatera, dan sebagian Sulawesi (Afgani dan Husain, 2018; Nurbaity dan Saring, 2015; Pradadimara, 2018; Yuwono, 2018; Zubir, 2019).

Demi memperlancar kapital yang dieskpor, pemerintah Hindia Belanda menguasai seluruh daerah nusantara melalui campur tangan politik dan militer. Setelah menguasai Jawa, pihak kolonial memperkuat dan meluaskan kekuasaannya di luar pulau itu, seperti di Lombok, Banjarmasin, Jambi, Riau, Aceh, Bone, dan termasuk Flores. Penguasaan wilayah di luar Jawa ini mengikuti tradisi lama perseroan dagang VOC, yakni monopoli perdagangan melalui perjanjian-perjanjian dengan para penguasa lokal.
Di Sulawesi Tengah, misalnya, Belanda menandatangani kontrak dengan pemerintahan lokal yang bertujuan untuk menegakkan kekuasaan dan mengatur perdagangan tanpa keterlibatan pemerintah secara langsung (Weber et al., 2003). Begitu juga dengan wilayah Flores, Belanda melakukan kontrol dari Timor dan Bima. Belanda baru resmi menjajah Flores pada tahun 1917-1918 setelah menaklukkan pemimpin lokal yang memberontak sejak tahun 1902 (Steenbrink, 2013; Tolo, 2016). Selama periode tersebut, sejumlah usaha dagang didirikan di Flores untuk menarik laba dari tanaman-tanaman produksi, seperti kapas, cengkih, kopra ataupun kelapa. ${ }^{1}$

Kajian tentang dinamika perdagangan kapas di Indonesia pada era kolonial sempat dibahas oleh Pierre van Der Eng (2013). Menurutnya, terjadinya pasang surut perdagangan dan industri tanaman produksi ini disebabkan oleh tiga faktor yaitu intensifikasi tenaga kerja, hampir tidak adanya produksi kapas mentah lokal, dan persaingan dagang dalam skala internasional. Sementara itu, untuk konteks Flores, perihal penanaman dan perdagangan kapas sejak masa pemerintahan Hindia Belanda hingga revolusi Indonesia pernah disinggung oleh Metzner (1982), tetapi dalam pranala sistem pertanian dan tekanan populasi penduduk di daerah tropis basah dan kering. Studi tersebut tidak membahas fakta kepengaturan dan relasi sosial ekonomi perdagangan tanaman komoditas tersebut.

Adapun studi-studi lainnya fokus pada aspek teknis pembuatan dan makna simbolik dari tenun ikat Flores sehingga mengabaikan analisis kesejarahan terkait produksi awal dan faktor penting yang menjadikan produk itu ada, yakni tanaman kapas (Elvida, 2015; Marlini et al., 2020; Octaviani dan Komalasari, 2020; Sanjaya, 2020). Studi ini bermaksud melengkapi kajian-kajian terdahulu berkaitan dengan aspek historis dan ekonomi politik dalam proses perdagangan kapas di wilayah Maumere,

\footnotetext{
${ }^{1}$ Sejarah kedatangan bangsa Portugis dan Belanda ke Pulau Flores bisa dilacak mundur sampai pada abad ke-16 (Barnes, 2010; Dietrich, 1983; Hägerdal, 2015).
} 
Flores tengah bagian timur, dari tahun 1912 hingga 1943. Perspektif ekonomi politik menaruh analisis pada faktor produksi-ekonomi dan hubungan sosial produksi dalam masyarakat dengan menyelidiki aspek historis dan konteks kekuasaaan politik yang bekerja (Dalton, 1977; Roseberry, 2003).

\section{Kajian Pustaka}

Di wilayah nusantara, tanaman kapas dibudidayakan di wilayah Sumatera dan Jawa bagian timur atau Bali. Letak daerah-daerah ini kebetulan berada di jalur perdagangan maritim (Destriana, 2014; Ekaputri, 2001). Di Flores, penduduk telah mengenal dan menanamnya sejak abad ke-12 atau sebelum Flores jatuh ke tangan Majapahit. Kapas dibawa oleh para pedagang dan pelayar dari Cina, India, Jawa, dan Gujarat, yang kemudian menetap di daratan. Kapas yang tumbuh dan berkembang di Flores memiliki jenis atau varietas berbeda-beda, tanaman ini dimanfaatkan juga oleh mereka yang pertama kali membawanya sebagai sarana pelindung tubuh dan pengembangan aktivitas subsistensi perladangan. Hal ini berlandaskan pada data arkeologis yang mencatat bahwa pada abad ke-8 SM, di sekitar lembah Sungai Indus, tanaman kapas telah dikembangkan, dipintal, dan ditenun (Gulati dan Turner, 1929). ${ }^{2}$

Di Flores, kapas tidak hanya menjadi bahan pembuatan tenun ikat bagi masyarakat setempat tetapi juga menjadi penanda status sosial ekonomi. ${ }^{3}$ Ada motif tenun yang hanya boleh dikenakan kepala suku dan raja; ada pula yang lebih cocok untuk dipakai rakyat jelata. Salah satu contohnya adalah motif ikat Patola di kalangan masyarakat suku Lio, Flores Tengah. Kain tenun itu hanya dibuat khusus untuk para kepala suku maupun kerabat kerajaan. Apabila warga biasa yang memakainya dipercaya akan muncul malapetaka.

Di Maumere, tanaman kapas mulanya banyak tumbuh di lokasi persinggahan awal orangorang yang datang dan menetap dari jalur pelayaran-perdagangan. Misalnya, di Kampung Sikka, di sebelah selatan Maumere pinggir laut Sawu, tenun ikat menjadi salah satu produk aktivitas domestik yang dilakukan kaum perempuan. Sikka sendiri merupakan salah satu etnis nenek moyang orang Maumere, yang kemudian berubah menjadi kerajaan berpengaruh di daratan Flores, dan menjadi nama kabupaten hingga sekarang. ${ }^{4}$

Rempe Sikka adalah salah satu motif tenun yang menyimbolkan penghormatan terhadap Raja Don Alesu Ximenes da Silva. Dia adalah Raja Sikka ketiga atau raja pertama dalam penguasaan Portugis, yang dianggap memperkenalkan tradisi menenun bagi warganya. Ini menunjukkan bahwa sejak era kolonial Portugis, tanaman kapas telah semakin banyak dibudidayakan oleh masyarakat Flores. Tekstil ataupun kain tenun menjadi salah satu komoditas penting dalam menjaga relasi perdagangan, terutama antara VOC dengan para elite lokal yang menjadi konsumennya. ${ }^{5}$ Kain itu juga menjadi upeti atau pajak dari rakyat untuk raja mereka sebagaimana terjadi juga di kehidupan orang Aztec, Cina, dan Afrika (Beckert, 2017).

Namun, perkembangan pembuatan tenun atau kain dalam skala rumah tangga di Flores tidak terlalu mengalami kemerosotan dibandingkan dengan yang terjadi di Jawa karena tidak mengalami dampak dari diberlakukannya

\footnotetext{
${ }^{2}$ Di kalangan suku Maya, kapas telah digunakan sejak tahun 632 SM, dan industri kapas berkembang antara tahun $100 \mathrm{SM}$ dan $300 \mathrm{M}$ di dataran rendah Veracruz, Mexico (Beckert, 2017).

${ }^{3}$ Sebelum era kolonialisme, tenun ikat ataupun tekstil telah menjadi alat tukar dan sering dipakai sebagai pemberian hadiah, selain menyimbolkan unsur religi atau kosmologi tertentu (Meerkerk, 2018).

${ }^{4}$ Di Kabupaten Sikka, terdapat kurang lebih lima etnis besar, yakni Sikka Krowe, Lio, Tana Ai, Palue, dan Tidung Bajo.

${ }^{5}$ Sebagaimana dijelaskan Meerkerk (2018), tekstil dari India dikirim ke nusantara untuk dikonsumsi oleh penguasa pribumi sebagai bagian dari strategi monopoli perdagangan oleh VOC. Di India sendiri kapas dianggap sebagai "emas putih" dan "raja tanaman serat" yang memiliki status unggul di antara semua tanaman komersial pada waktu itu.
} 
politik penjajahan Tanam Paksa (1830-1870). ${ }^{6}$ Kebijakan Tanam Paksa dan hasrat Amsterdam menjadi importir tekstil dunia menjadi dua dari sekian banyak faktor menurunnya pertumbuhan industri manufaktur tekstil di kalangan masyarakat Jawa (Meerkerk, 2018; Van Der Eng, 2006). Baru setelah Tanam Paksa dihapuskan dan Undang-Undang Agraria 1870 ditetapkan, sistem kapitalisme mulai benar-benar bekerja di seluruh Indonesia. Artinya, pemerintah Hindia Belanda memberikan kebebasan investasi bagi modal partikelir untuk menguasai dan mengontrol sumber daya alam serta pasar yang ditandai dengan munculnya sektor-sektor agroindustri.

\section{Metode}

Penelitian ini dilakukan dengan metode studi pustaka. Data-data dikumpulkan dari jurnal, buku, manuskrip, dan literatur-literatur lain yang berkaitan dengan sejarah budidaya dan perdagangan kapas di Flores pada masa kolonial Belanda. Hasil studi literatur disusun dan dianalisis untuk memberikan gambaran mengenai proses introduksi kapas sebagai tanaman perdagangan di Pulau Flores, relasi kekuasaan antara pemerintahan kolonial dengan penguasa lokal, dan bagaimana masyarakat terjebak dalam bisnis kapas mentah yang berujung pada kemelaratan diri mereka sendiri.

\section{Hasil dan Pembahasan}

\section{Dari Uji Coba hingga Perampasan Lahan}

Dua puluh tahun sejak Belanda mengambil alih Sunda Kecil dari tangan Portugis, tepatnya tanggal 24 Agustus 1879, G. A. van Siek ditempatkan di Maumere sebagai seorang posthouder. Posthouder adalah pejabat sipil yang bertanggung jawab untuk urusan perdagangan. Van Siek yang diutus dari Residentie Timor en Onderhoorigheden (Keresidenan Timor dan sekitarnya) yang berpusat di Kupang, Timor Barat, bertugas memantau wilayah koloni baru dan aspek perekonomian apa yang dapat dikeruk. ${ }^{7}$ Kemudian, Van Siek melakukan pendekatan dengan Raja Andreas Djati Da Silva (1874-1898) dari Kerajaan Sikka. Pendekatan ini mudah dilakukan sebab Sikka sendiri sebelumnya telah terkooptasi ke dalam kekuasaan Portugis. ${ }^{8}$ Raja Djati pun dibujuk untuk memindahkan pusat kekuasaannya dari Kampung Sikka di pantai selatan ke wilayah Maumere, mengingat letaknya yang strategis sebagai kota dagang dan pusat usaha para pedagang Cina. ${ }^{9}$ Namun, rencana ini baru terwujud pada masa kekuasaan Raja Josephus Nong Meak Da Silva, yang ditetapkan menjadi Raja Sikka pada tahun 1902. Secara formal, pada tahun tersebut ibu kota pemerintahan Kerajaan Sikka pun berpindah ke Maumere yang berhadapan langsung dengan Laut Flores (Lewis, 2010).

Sepuluh tahun kemudian, pada 1912 pemerintah Hindia Belanda memfasilitasi pendirian sebuah usaha dagang privat bernama Syndicaat ter Bevordering van de Katoencultuur op Flores. Usaha dagang ini fokus mengembangkan produksi tanaman kapas dan diizinkan beroperasi tahun 1915 (Metzner, 1982). Pemberian izin

\footnotetext{
${ }^{6}$ Setelah kebangkrutan VOC dan berakhirnya perang Napoleon di Eropa, pemerintah Belanda mengembangkan rencana untuk memajukan industri tekstil di wilayah Belgia yang baru saja diakuisisi. Oleh sebab itu, pemerintah Belanda memberikan monopoli atas seluruh perdagangan yang dilakukan antara Belanda dan Indonesia kepada Nederlandsche Handel Maatschappij (NHM), sebuah perusahaan swasta yang didirikan tahun 1824 (Van Der Eng, 2006).

${ }^{7}$ Meskipun demikian, Residentie Timor en Onderhoorigheden barulah terbentuk secara struktural dan mapan sekitar akhir tahun 1911 hingga Agustus 1913 dengan luas wilayah $63.551 \mathrm{~km}^{2}$, suatu wilayah yang luasnya dua kali lipat dari Belanda (Ardhana, 2005).

${ }^{8}$ Kerajaan warisan Portugis lain yang juga diserahkan ke Belanda ialah Nita, tetapi di sebelah timur Maumere ada kerajaan KangaE dari kekuasaan Sriwijaya yang tidak mendapatkan pengaruh apa-apa dari Portugis serta kerap melakukan perlawanan terhadap Belanda hingga tahun 1902 (Diogo, 2009).

${ }^{9}$ Untuk konteks Kepulauan Sunda Kecil, pusat-pusat perdagangan baru pun tersebar di Kupang, Ende, Sumba, juga Maumere yang ditandai dengan beroperasinya perusahaan pelayaran baru, Koninklijke Paketvaart Maatschappij (KPM). KPM secara resmi memperoleh hak monopoli pada tahun 1889, dan dua tahun sesudahnya dari pelabuhan Singapura melintasi sejumlah pelabuhan di Hindia Belanda, termasuk Maumere, Ende, dan Larantuka, yang
} 
ini merupakan ide dari inspektur perkebunan pemerintah kolonial Dr. Van Breda de Haan. Operasi perusahaan berada di bawah tanggung jawab lembaga Landbouw Voorlichtingsdienst yang didirikan di Ende, ibu kota Afdeeling Flores, tahun $1910 .{ }^{10}$ Faktor lainnya juga disebabkan oleh semakin redanya gejolak politik lokal dan terutama takluknya Kerajaan KangaE di sebelah timur Maumere. Penyerangan oleh serdadu Marsose utusan petinggi KNIL pada 26 November 1902 menyebabkan kerajaan ini berhasil dikendalikan Belanda (Diogo, 2009).

Meskipun begitu, pada tahun 1912, pemerintah kolonial mulanya melakukan uji coba penanaman seiring dengan pengadaan mesin pemintal kapas sebelum memberikan izin konsesi lahan. Pengamatan bahwa kapas telah banyak diolah oleh masyarakat Flores sebagai bahan produksi tenun ikat ratusan tahun lamanya menjadi salah satu alasan tanaman ini, dalam bentuk kapas mentah, hendak dijadikan komoditas dalam rantai kapitalisme global. Apalagi sejak akhir abad ke-19, kebutuhan pabrik Eropa atas kapas mentah mengalami peningkatan luar biasa. ${ }^{11}$ Di Inggris hampir tidak ada pabrik yang mempekerjakan lebih banyak buruh ketimbang pabrik tekstil berbahan baku kapas. Kebutuhan kapas memainkan posisi penting sama seperti kebutuhan akan minyak pada abad ke-21 (Beckert, 2017).

Uji coba penanaman kapas oleh pemerintah dilakukan di Kampung Bebeng, sebuah wilayah di sebelah barat Maumere dan merupakan salah satu pelabuhan tertua di Flores. ${ }^{12}$ Bebeng terletak di sekitar tempat labuhan kapal dan masuk dalam wilayah kekuasaan Kerajaan Sikka yang memudahkan pelaksanaan uji coba varietas kapas asal Australia dan Amerika Selatan. Kapal pengangkut berlabuh, lalu benih biji kapas tinggal disebar. Penanaman ini berlangsung selama tiga tahun. Kemudian, sebagaimana tertuang dalam Surat Keputusan Residen Timor en Onder Hoorigheden, Nomor 264, 11 September 1912, pada tahun 1915 perusahaan mendapatkan izin operasi di wilayah Nangahale. Daerah tersebut berada di pesisir Flores yang berjarak sekitar 60 kilometer ke arah timur dari Maumere (Metzner, 1982).

Jauh sebelumnya Nangahale memang telah dilirik oleh pemerintah kolonial guna pengembangan kapas dan perkebunan kelapa. Tahun 1902 menjadi penanda penting dalam penaklukan elite aristokrasi Maumere dengan runtuhnya Kerajaan KangaE. Kemudian, Belanda dengan posthouder-nya, B.L. Kailola, membentuk Kerajaan Tana Ai yang wilayah operasinya mencakupi Nangahale dengan rajanya bernama Nai Roa.

Raja ini secara paksa menyuruh penduduk tempatan, yakni orang-orang suku Soge dan Goban, berpindah ke wilayah dataran tinggi. Raja beralasan kalau tempat tinggal mereka rawan malaria, sering terjadi banjir, dan kerap jadi arena pertempuran antarkampung (Prior, 2013). Namun, orang-orang itu tidak mau pindah. Berpindah berarti mereka perlu mengeluarkan lebih banyak energi untuk aktivitas pertanian atau perladangan hutan juga pemeliharan ternak dan harus mengarungi risiko subsistensi yang lebih besar.

Menghadapi penolakan ini, Raja Nai Roa dengan persetujuan diam-diam dari pemerintah kolonial, mengirim utusannya untuk membakar kampung Nangahale. Penduduk pun lari terbirit-birit ke balik perbukitan dan terpaksa harus membangun ulang perkampungan dan bekerja lebih keras guna bertahan hidup. Tanah yang mereka tinggalkan itu, dibersihkan kemudian berubah menjadi area pengembangan kapas seluas 1.450 hektar oleh perusahaan.

mana telah dibangun juga kantor-kantor agen (Kartika, 2009).

${ }^{10}$ Pelabuhan Ende terletak strategis di pantai selatan Pulau Flores dan menghadap ke Laut Sawu, yang merupakan jalur perdagangan yang baik karena ada pelayaran di sepanjang pantai (Anita dan Sulaiman, 2021).

${ }^{11}$ Di dalam hubungannya dengan kolonialisme global, antara tahun 1860 hingga 1920, terdapat kurang lebih 55 juta hektar tanah baru di Asia, Amerika, dan Afrika yang disulap menjadi area penanaman kapas untuk pasar dunia (Beckert, 2017).

${ }^{12}$ Sejak abad ke-17 tempat ini merupakan salah satu wilayah persinggahan para pelaut dan pedagang Suku Bajo. Di dalam hikayat Kerajaan Sikka disebutkan bahwa Wuring, sebuah pantai di sebelah Bebeng, menjadi lokasi di mana Raja Don Alesu berangkat melakukan pelayaran ke Malaka (De Porres, 2021; Lewis, 2010). 
Ironisnya, Syndicaat ter Bevordering van de Katoencultuur op Flores hanya beroperasi selama dua tahun. Perusahaan gulung tikar akibat krisis finansial, dan kemudian diambil alih oleh perseroan lainnya N.V. Amsterdam Soenda Compagnie yang berpusat di Ende (Metzner, 1982). Kapas-kapas mentah dari wilayah Afdeeling Flores selanjutnya dikirimkan ke Ende untuk diubah menjadi katun lalu diekspor ke luar negeri, seperti ke Belanda, Inggris Raya, Amerika, Jepang, Australia, dan Selandia Baru. Penduduk tempatan pun didesak untuk melakukan penanaman kapas dengan koordinasi langsung dari para raja lokal yang telah ditaklukkan dan diangkat tadi.

Secara khusus, kapas juga dikembangkan di wilayah sekitar kerajaan. Misalnya di wilayah Kerajaan Sikka pengembangan kapas dilakukan di Misir, dua kilometer arah selatan dari Maumere, juga di Lela yang berdekatan dengan Kampung Sikka dengan luasnya kurang lebih mencapai 10 hektar. Kapas ditanam bersama dengan komoditas jagung, tetapi mereka tidak punya posisi tawar karena harga jual ditetapkan oleh pemerintah. Mantri atau penyuluh pertanian juga diterjunkan ke kampung-kampung, seperti di Kewa, Wetakara, Guru, Ribang, dan Letet, untuk memperkenalkan bibit berkualitas dan mengajari penduduk guna menggenjot aktivitas penanaman.

Di sisi lain, penduduk yang dipaksa menanam kapas tetapi tidak punya posisi tawar dalam menentukan harga, juga harus membayar pajak dalam bentuk uang. Sebagaimana terjadi di Onderafdeeling Ende, pajak yang dibebankan kepada tiap kepala oleh pemerintah kolonial adalah sekitar $4 \%$ dari pendapatan, dengan jumlah paling sedikit yang dibayarkan sebesar 2 gulden per tahun (Kartika, 2009). Di samping itu, mereka juga mesti bekerja di lahan-lahan yang dikuasai oleh raja dan kerabatnya karena kepala perusahaan dagang di Ende mendesak produktivitas tanaman komoditas ini.

\section{Hari-Hari Tanpa Harapan}

Pemerintah kolonial tampaknya berniat menjadikan Flores sebagai basis industri katun di seluruh wilayah Hindia Belanda (Kartika, 2009). Oleh sebab itu, setelah di Maumere, pabrik mesin pemintal kapas dibangun pula di Ende dengan biaya sebesar 50 ribu florin. Hal ini sebenarnya tidak mengherankan sebab roda perekonomian Hindia Belanda memang bergantung pada komoditas ekspor. Komoditas kunci lain di Flores yang juga berpengaruh ialah kopi dan kelapa. Namun, karena terjebak dalam rantai kapitalisme global, maka ketika krisis ekonomi atau Depresi Besar 1930 melanda, harga bahan mentah dari tanah jajahan serta merta mengalami penurunan signifikan. ${ }^{13}$

Perang Dunia I, yang berlangsung antara 1914 dan 1918, menyebabkan terganggunya moda transportasi perkapalan yang kemudian berdampak pada jatuhnya impor kapas (Van Der Eng, 2006). Dengan demikian, pabrik yang didirikan di Ende menjadi tidak berfungsi; perusahaan tidak lagi mampu membeli kapas dari penduduk sesuai harga yang mereka tetapkan sebelumnya. Bahkan, pemerintah pun menolak pengajuan kredit pinjaman oleh perusahaan.

Tahun 1924, N.V. Amsterdam Soenda Compagnie benar-benar mengalami pailit. Lalu, supaya situasi keterjepitan tidak kian parah, perusahaan menjual sebagian lahan produksi kapas di Nangahale tadi ke pihak misionaris gereja Katolik, Vikariat Apostolik Kepulauan Sunda Kecil, dengan harga 22.500 florin (Metzner, 1982; Prior, 2013). Tanah penjualan tersebut kemudian disulap untuk pembukaan perkebunan kelapa yang berlangsung secara masif oleh misi gereja Katolik. ${ }^{14}$ Penjualan ini sepertinya memang dilakukan karena keterpaksaan. Toh sebelumnya misi gereja Katolik di Hindia Belanda sengaja dirintangi pemerintah kolonial karena kecemasan atas propaganda misi yang

\footnotetext{
${ }^{13}$ Secara garis besar, dampak paling nyata dari Depresi Besar 1930 terjadi pada volume ekspor, harga ekspor, dan suplai uang riil. Antara 1928 dan 1934 terjadi penurunan volume ekspor hampir 4 persen per tahun, harga ekspor hampir 20 persen per tahun, dan suplai uang riil lebih dari 2 persen per tahun (Booth, 1998).

${ }^{14}$ Pemerintah kolonial memang telah menetapkan bahwa kopra adalah jawaban untuk kurangnya surplus yang diproduksi oleh sistem ekonomi subsisten di wilayah itu (Klinken, 2015).
} 
diduga dapat meningkatkan semangat kemandirian rakyat bumiputra.

Penjualan tanah hasil rampasan ke pihak gereja Katolik tidak sepenuhnya menyelesaikan krisis perusahaan yang otomatis berdampak pada keistimewaan negara kolonial. Hampir sebagian besar penduduk di Maumere menolak mengusahakan tanaman komoditas tersebut. Ini bukan soal penurunan drastis dari kepercayaan diri mereka (Metzner, 1982; Utomo, 2020), tetapi rangkaian dari suatu sistem pengerukan kapital berlapis-lapis kolaborasi elite feodal dan kekuasaan kolonial yang membentuk semacam relasi patron-klien. Lagi pula dalam struktur masyarakat petani seperti itu para petani sebenarnya tidak punya kepercayaan diri sama sekali. Mereka sudah bekerja terlalu keras dan nyawanya bisa terancam kalau harus bekerja lebih keras lagi. Tanpa adanya proses akumulasi primitif ${ }^{15}$ semacam ini, mustahil sistem kapitalisme berupa komersialisasi tanaman produksi, atau dalam istilah Bharadwaj (1985) pemaksaan komersialisasi, bisa berjalan lancar. Perdagangan dan pajak tidaklah berbeda dengan mekanisme pengerukan surplus kerja.

Akibat kondisi tersebut, pemerintah kolonial terpaksa memutar otak. Pada tahun 1928, ekspansi perkebunan kapas pun berlanjut ke Onderafdeeling Ngada, di wilayah Flores bagian tengah. Tidak tanggung-tanggung, sekitar 45 ribu hektar tanah dikuasai dan dijual ke pengusaha untuk dikelola menjadi perkebunan kapas (Kartika, 2009). Tidak ditemukan data pasti siapa pengusaha perkebunan itu. Kemungkinan besar sebagian tanah-tanah tersebut juga dijual ke pihak gereja. Mereka adalah misionaris gereja Katolik dari Societas Verbi Divini (SVD) yang pada tahun 1928 sedang membangun lembaga pendidikan seminari menengah calon pastor Katolik di wilayah Mataloko, bagian dari Onderafdeeling Ngada. Seminari ini sebelumnya didirikan di
Kampung Sikka pada tahun 1926. Dengan kata lain kebijakan Politik Etis - dalam artian tertentu - hanyalah kedok untuk menyelamatkan muka pemerintah kolonial yang tengah dicekik krisis. Tolo (2016) menyebutnya sebagai usaha Belanda memperluas "kedaulatan atas tanah" di Hindia Belanda, khususnya di daerah luar Jawa.

Puncak krisis ekonomi dunia pada tahun 1930 memberikan pukulan telak bagi perekonomian Hindia Belanda, termasuk di wilayah jajahan Keresidenan Timor dan sekitarnya. Penduduk dikabarkan menderita kelaparan luar biasa, sehingga pemerintah kolonial harus mengangkat seorang penasihat pertanian (Kartika, 2009). Namun, solusi tersebut tetap tidak berdaya menyelesaikan persoalan penderitaan penduduk tempatan. Pasalnya, kepanikan atas krisis membuat Raja Sikka yang berkuasa kala itu, Don Thomas Ximenes Da Silva, mengeklaim hampir seluruh lahan di wilayah landschap Sikka ${ }^{16}$, yang kemudian dijadikan sebagai tanah bengkok. Tanah-tanah yang belum ditempati ataupun digarap kemudian dijual ke para pedagang Bugis dan Cina. Kemudian, sisanya dikuasai oleh kalangan kerabat raja dan keluarga kapitan penguasa hamente yang berada dalam struktur kekuasaan landschap Sikka.

Penanaman kapas di Flores, terutama di Maumere, terus berlanjut pada masa penjajahan Jepang. Pada tahun 1943, salah satu perusahaan Jepang menanam varietas baru di atas lahan seluas seribu hektar di Waigete, daerah sebelum Nangahale, dan di Wailiti, sebelah kanan dari Bebeng. Di samping itu, tanah caplokan di Nangahale tadi yang dibeli misi gereja Katolik untuk perkebunan kelapa juga diserahkan ke pihak gereja lokal, yakni Keuskupan Agung Ende, sebagai penerus legal di bawah Vikariat Apostolik Kepulauan Sunda Kecil.

\footnotetext{
${ }^{15}$ Teori akumulasi primitif dikembangkan oleh Karl Marx, merespons konsep yang sebelumnya dilontarkan Adam Smith. Teori ini fokus pada gagasan bahwa kapital dan tertimbunnya kekayaan kelas pemilik sarana produksi merupakan hasil perampasan terhadap kekayaan sosial hasil kerja golongan lain (Mulyanto, 2008).

${ }^{16}$ Pada 14 November 1925, pemerintah kolonial meleburkan kerajaan-kerajaan di Onderafdeeling Maumere ke dalam sebuah kekuasaan sentral, disebut landschap, dengan pemimpinnya dari Kerajaan Sikka (Diogo, 2009).
} 


\section{Simpulan}

Masyarakat Flores mulanya menanam kapas untuk kepentingan subsistensi hidup. Kapas mentah diolah sebagai bahan pembuatan kain yang berfungsi sebagai sarana pelindung dan penutup tubuh. Tanaman kapas tersebar berkat migrasi penduduk dari India, Jawa, Gujarat, dan Cina, terutama pada masa kerajaan Majapahit.

Perubahan dimulai ketika Portugis menguasai Flores dan membentuk elite-elite feodal lokal, seperti yang terjadi di wilayah Sikka dan Nita di Maumere. Kapas dan kain tenun berubah menjadi simbol kekuasaan sosial ekonomi beriringan dengan semakin masifnya pengenalan alat tenun. Raja dan kerabatnya awalnya hanya menjadi konsumen, tetapi kemudian memaksa rakyatnya giat mengerjakan tenun ikat untuk dijadikan upeti. Di kalangan rakyat sendiri, penanaman kapas dan pengerjaan tenun ikat juga menjadi alat pertukaran ekonomi, termasuk untuk kepentingan ritual dan upacara-upacara.

Perubahan kembali terjadi pada awal abad ke-20, ketika pemerintah Hindia Belanda berhasil mematahkan perlawanan penduduk lokal, kapas diubah menjadi salah satu komoditas untuk kepentingan komersial. Usaha dagang besar pun diizinkan beroperasi disertai dengan pengenalan bibit-bibit baru yang dianggap dapat meningkatkan produksi ekspor. Investasi kapital ini membuat sebagian penduduk harus kehilangan lahan dan tempat tinggal, seperti yang dialami oleh masyarakat Nangahale, di wilayah Maumere bagian timur. Pemerintah kolonial tinggal memerintah para raja lokal yang telah dikuasai untuk mengusir penduduk dan pada saat bersamaan memberikan perintah penanaman bibit kapas ke penduduk lainnya. Sebagaimana sebelumnya terjadi di Jawa, kapas pun menjadi salah satu komoditas tanam paksa yang digenjot pemerintah kolonial mengingat harganya di pasaran dunia yang tengah melambung tinggi.

Namun, depresi besar tahun 1930 menyebabkan anjloknya harga tanaman-tanaman komoditas. Kapal pengangkut mengalami kendala dalam operasinya sehingga kapas mentah hasil tanam paksa itu dibiarkan mubazir belaka. Rakyat yang tenaga kerjanya telah banyak dikuras untuk melayani raja dan kerabatnya pun memutuskan untuk tidak mau lagi menanam kapas untuk kepentingan komersialisasi. Kelaparan yang melanda wilayah Hindia Belanda menjadi faktor kunci lain adanya pembangkangan termaktub.

Tepat pada masa krisis ekonomi tersebut, penguasa landschap tempatan bentukan pemerintah kolonial, yakni Raja Sikka, menegakkan klaim kepemilikan tanah di Maumere. Rakyat jajahan yang telah melarat dalam kerangkeng komersialisasi kapas menjadi kian melarat karena tidak punya akses dalam mengusahakan faktor produksi alami. Dibutuhkan studi lebih lanjut yang bersifat empiris dengan pembacaan terhadap sumber-sumber primer. Studi empiris dilakukan untuk memeriksa rangkaian relasi sosial dan ekonomi politik dalam sejarah perdagangan tanaman kapas di Flores.

\section{Referensi}

Afgani, R., dan Husain, S. B. (2018). Manisnya Kopi di Era Liberal: Perkebunan Kopi Afdeling Malang, 1870-1930. Indonesian Historical Studies, 2(1), 24. https://doi. org/10.14710/ihis.v2i1.3199

Anita, dan Sulaiman, H. (2021). The Existence of the Port of Ende in 19th Century Sailing and Trade in Nusa Tenggara. Santhet: Jurnal Sejarah, Pendidikan, dan Humaniora, 5(1), 44-56. https://doi.org/10.36526/js.v3i2

Ardhana, I. K. (2005). Pemerintahan Pusat dan Swapraja: Masalah Sentralisasi dan Desentralisasi. Jurnal Masyarakat dan Budaya, 7(2), 43-56. https://doi.org/10.14203/jmb. v7i2.226

Barnes, R. H. (2010). Raja Servus of Larantuka, Flores, Eastern Indonesia. Moussons, 16, 3956. https://doi.org/10.4000/moussons. 180

Beckert, S. (2017). Cotton and the Global Origins of Capitalism. Journal of World History, 28(1), 107-120. https://doi.org/10.1353/ jwh.2017.0004

Bharadwaj, K. (1985). A View on Commercialisation in Indian Agriculture and the Development of Capitalism. The Journal of Peasant Studies, 12(4), 7-25. https://doi. org/10.1080/03066158508438273

Booth, A. (1998). The Indonesian Economy in the 
Nineteenth and Twentieth Centuries. Didalam The Indonesian Economy in the Nineteenth and Twentieth Centuries. St. Martin's Press. https://doi.org/10.1057/9780333994962

Dalton, G. (1977). Economic Anthropology. American Behavioral Scientist, 20(5), 635-656. https://doi. org/10.1177/000276427702000504

De Porres, M. E. (2021). Dinamika Sosial Ekonomi Nelayan Kampung Wuring di Pesisir Utara Flores. Jurnal Paradigma: Jurnal Multidisipliner Mahasiswa Pascasarjana Indonesia, 2(1), 19-26.

Destriana, N. (2014). Perdagangan Kapas pada Masa Bali Kuno Berdasarkan Prasasti Kintamani D dan E (Kajian Epigrafi). Humanis, 7(2), 1-8.

Dietrich, S. (1983). Flores in the Nineteenth Century: Aspects of dutch colonialism on a non-profitable island. Indonesia Circle. School of Oriental dan African Studies. Newsletter, 11(31), 39-58. https://doi. org/10.1080/03062848308729554

Diogo, L. (2009). Kisah Kerajaan Tradisional Kangae Aradae Nian Ratu Tawa Tanah. Manuskrip. Kewapante.

Ekaputri, R.A. (2001). Kapas dan Ekonomi Penduduk Keresidenan Palembang (Pertengahan Abad XIX-Awal Abad XX). Lembaran Sejarah, $4(1), 24-53$.

Elvida, M. N. (2015). Pembuatan Kain Tenun Ikat Maumere di Desa Wololora Kecamatan Lela Kabupaten Sikka Provinsi Nusa Tenggara Timur. HOLISTIK, Journal of Social and Culture, 8(16), 1-22.

Gulati, A. N., dan Turner, A. J. (1929). 1-A Note on the Early History of Cotton. Journal of the Textile Institute Transactions, 20(1), T1-T9. https://doi. org/10.1080/19447022908661470

Hägerdal, H. (2015). Eastern Indonesia and the Writing of History. Archipel, 90, 75-97. https://doi.org/10.4000/archipel.369

Kartika, F. I. (2009). Pelabuhan Ende dalam Jaringan Pelayaran di Kawasan Laut Sawu dan Sekitarnya 1839-1930. Skripsi. Universitas Indonesia.

Klinken, G. van. (2015). Pembunuhan di Maumere: Kewarganegaraan Pascapenjajahan. Jurnal Ledalero, 14(1). https://doi.org/10.31385/ jl.v14i1.2.11-33

Lewis, E. D. (2010). The Stranger-Kings of Sikka. KITLV Press.

Marlini, S., Murniasih, A. A. A., dan Kaler, I. K.
(2020). Peranan Sanggar Watu Bo dalam Produksi Tenun Ikat Tradisional Desa Kajowair. Humanis, 24(3), 314-321. https://doi. org/10.24843/JH.2020.v24.i03.p11

Meerkerk, E. van N. (2018). Threads of Imperialism Colonial Institutions and Gendered Labour Relations in the Textile Industry in the Dutch Empire. Di dalam K. Hofmeester dan P. de Zwart (Eds.), Colonialism, Institutional Change, and Shifts in Global Labour Relations (hal. 135-172). Amsterdam University Press. https://doi. org/10.1515/9789048535026-006

Metzner, J. K. (1982). Agriculture and Population Pressure in Sikka, Isle of Flores. The Australian National University.

Mulya, L. (2018). Kebijakan Maritim di Hindia Belanda: Langkah Komersil Pemerintah Kolonial. MOZAIK: Jurnal Ilmu-Ilmu Sosial Dan Humaniora, 7(1). https://doi.org/10.21831/ moz.v7i1.5543

Mulyanto, D. (2008). Konsep Proletarisasi dan Akumulasi Primitif dalam Teori Kependudukan Marxis. Jurnal Kependudukan Padjadjaran, 10(2), 81-99.

Nurbaity, dan Saring. (2015). Swastanisasi Perkebunan Teh di Bogor 1905-1942. Sosio-E-Kons, 7(3), 216-226. http://dx.doi. org/10.30998/sosioekons.v7i3.698

Octaviani, L. K., dan Komalasari, S. A. (2020). Kain Tenun Ikat sebagai Wisata Budaya Kabupaten Sikka. Kepariwisataan: Jurnal Ilmiah, 14(3), 151-159.

Pradadimara, D. (2018). Coffee Economy in Late Colonial Netherlands East Indies: Estates and Capital, 1890-1940. Lembaran Sejarah, 13(1), 5. https://doi.org/10.22146/lembaran-sejarah.33509

Prior, J. M. (2013). Land Disputes and the Church: Sobering thoughts from Flores. Di dalam A. Lucas dan C. Warren (Eds.), Land for the people: the state and agrarian conflict in Indonesia. Ohio University Press.

Roseberry, W. (2003). Political Economy. Annual Review of Anthropology, 17(1), 161-185. https://doi.org/10.1146/annurev. an.17.100188.001113.

Sanjaya, F. (2020). Pemaknaan Motif Tokek pada Kain Tenun Utan Welak Maumere. Oratio Directa, 2(2), 251-265.

Sondarika, W. (2015). Dampak Culturstelsel (Tanam Paksa) bagi Masyarakat Indonesia dari Tahun 1830-1870. Jurnal Artefak, 3(1), 59-66. https://doi.org/10.25157/ja.v3i1.337 
Steenbrink, K. (2013). Dutch Colonial Containment of Islam in Manggarai, West-Flores, in Favour of Catholicism, 1907-1942. Bijdragen Tot de Taal-, Land- En Volkenkunde/Journal of the Humanities and Social Sciences of Southeast Asia, 169(1), 104-128. https://doi.org/10.1163/22134379-12340024

Tolo, E. Y. S. (2016). Akumulasi Melalui Perampasan dan Kemiskinan di Flores. MASYARAKAT: Jurnal Sosiologi, 21(2), 173-204. https:// doi.org/10.7454/mjs.v21i2.5478

Utomo, I. N. (2020). Depresi Ekonomi dan Krisis Kepercayaan Rakyat terhadap Pemerintah Kolonial 1930-1936. Sejarah dan Budaya: Jurnal Sejarah, Budaya, dan Pengajarannya, 14(1), 62-75. https://doi.org/10.17977/um020v14i12020p62

Van Der Eng, P. (2006). De-industrialisation' and Colonial Rule: The Cotton Textile Industry in Indonesia, 1820-1941 (2007/04). Departmental Working Papers, (2007-04). The Australian National University, Arndt-Corden Department of Economics

Van Der Eng, P. (2013). Why Didn't Colonial Indonesia Have a Competitive Cotton Textile Industry? Modern Asian Studies, 47(3), 1019-1054. https://doi.org/10.1017/ S0026749X12000765

Weber, R., Kreisel, W., dan Faust, H. (2003). Colonial Interventions on the Cultural Landscape of Central Sulawesi by "Ethical Policy": The impact of the Dutch Rule in Palu and Kulawi Valley. Asian Journal of Social Science, 31(3), 398-437. https://doi. org/10.1163/156853103322895324

Yuwono, P. S. H. (2018). Vanishing Frontiers: A Javanese Plantation Emplacement, 1870s2000s. Jurnal Humaniora, 30(1), 67. https:// doi.org/10.22146/jh.v30i1.33431

Zubir, Z. (2019). Sejarah Perkebunan dan Dampaknya bagi Perkembangan Masyarakat di Onderafdeeling Banjoeasin En Koeboestrekken, Keresidenan Palembang, 1900-1942. Jurnal Penelitian Sejarah dan Budaya, 1(1), 79101. https://doi.org/10.36424/jpsb.v1i1.109

Zulkarnain. (2010). Serba-serbi Tanam Paksa. ISTORIA, 8(1), 30-46. https://doi.org/10.21831/ istoria.v8i1.3720 